\title{
A PRESIDÊNCIA IMPERIAL E 0 TERROR DE ESTADO
}

\author{
SAXE-FERNÁNDEZ, John \\ Terror e Império: la hegemonia política y econômica de \\ Estados Unidos \\ México, DF: Editora Debate, 2006.
}

\section{POR}

\section{Waldir José Rampinelli ${ }^{1}$}

\begin{abstract}
0 s impérios, ao longo da história, têm se utilizado do mecanismo do medo e do instrumento do terror para submeter povos e extrair seu excedente econômico. Não apenas a forma do colonialismo marcou este enriquecimento ilícito e criminoso, como também a idéia da colonialidade, isto é, uma classificação social a partir de critérios étnicos e raciais. Ser cidadão romano na Antiguidade Clássica ou cidadão estadunidense na Época Contemporânea indica não apenas uma procedência geográfica, mas também uma conotação de superioridade: um civilizado portador de direitos diante de um bárbaro sem história.

John Saxe-Fernández, em seu livro Terror e Império - La hegemonia política y econômica de Estados Unidos analisa, em uma série de ensaios, o conceito depresidência imperial; o capital monopolista e a economia permanente

\footnotetext{
${ }^{1}$ Professor do Departamento de História da Universidade Federal de Santa Catarina, com doutorado em Ciências Sociais-Política pela Pontifícia Universidade Católica de São Paulo. End. eletrônico: rampinelli@globo.com
} 
de guerra; a expropriação dos recursos latino-americanos; 0 terror de Estado e sua administração colonial; a crise da pax americana e a economia de guerra; e a destruição da democracia representativa dentro dos Estados Unidos por meio da Lei Patriota, entre outros temas.

0 conceito depresidência imperial, para Saxe-Fernández, ajuda a entender os rumos que norteiam o comportamento regional e internacional dos Estados Unidos, permitindo identificar as continuidades e descontinuidades desta projeção de poder desde a fundação da nação estadunidense no final do século XVIII até a crise da pax americana, nos tempos atuais. Define a presidência imperial como "a expressão institucional de uma realidade sistemática que surgiu da própria natureza do desenvolvimento capitalista ainda que, sem dúvida, o regime de exceção instaurado depois do 11 de setembro [de 2001] tenha acentuado de maneira inusitada a usurpação, por parte desta presidência, das funções legislativas e judiciárias em níveis ditatoriais (p. 15)". A presidência imperial, com sua tendência autocrática, operou historicamente nos Estados Unidos em diferentes esferas de poder, tais como: 1) no completo domínio territorial da América do Norte, quer obrigando a França a "vender" a Luisiânia, a Espanha a "ceder" a Flórida Ocidental, o México a "entregar" mais da metade de seu território e os indígenas a perder suas ricas terras; 2) na subjugação religioso-cultural, por meio da Doutrina do Destino Manifesto, fazendo crer que Deus havia delineado uma grande missão aos fundadores daquela nação, qual seja, levar a civilização aos bárbaros; 3) na não permissão da existência de qualquer potência, ou grupo delas, no Hemisfério Ocidental, que ameace a hegemonia econômico-militar dos Estados Unidos; e 4) no controle dos Estados Unidos sobre os oceanos, não permitindo que nações europeias e asiáticas criem algum tipo de dificuldade e orientando suas energias para ameaçar ou fazer guerras terrestres na Eurásia (p.16 ss.).

A ideia de presidência imperial "torna visível a interrelação entre os processos políticos, diplomáticos e militares com os de ordem econômicoempresarial e social, como o avanço da diplomacia econômica e das canhoneiras e sua relação com o surgimento dos grandes monopólios nos Estados Unidos desde a segunda metade do século XIX até os dias de hoje" (p. 23). A presidência imperial é, portanto, um tema com uma pauta imperialista. 


\section{A Presidência Imperial e o Triângulo de Ferro}

0 Triângulo de Ferro - composto pela burocracia federal sob o comando do Poder Executivo, pelos principais comitês do Congresso e pela cúpula empresarial e bancária - defende os interesses de uma classe que se apoderou do Estado por meio da presidência imperial, que, por sua vez, promove e apoia as vantagens dilapidadoras do grande capital, quer no exterior, quer dentro do próprio país. "0 Triângulo de Ferro", diz Saxe-Fernández, "é o fundamento sociológico de camarilhas cuja dinâmica gira em torno do interesse privado, especialmente dos grandes empórios empresariais e do grande poder, impulsionados pelos lobbies que estão a serviço das empresas multinacionais (p.126)". Para as indústrias de armamentos - denominadas por Eisenhower de complexo militar-industrial, que se consolidaram no pós-Segunda Guerra Mundial como um componente direto do processo de tomada de decisões dentro do Triângulo de Ferro - não funcionam as leis de mercado, mas sim um autêntico capitalismo de Estado. Não apenas os orçamentos são astronômicos, como também as compras estão garantidas, sendo os superfaturamentos uma prática constante. Guerras como a do Vietnã, a do Iraque e, agora, a do Afeganistão são provocadas pela presidência imperial com o objetivo de atender a estes grandes conglomerados dentro da estratégia do keynesianismo militar. 0 Grupo Dupont fez fortuna durante a Primeira Guerra Mundial deste modo, como mostram as audiências legislativas sobre a indústria dos armamentos e das munições.

Para atender ao poderoso lobby da guerra, o próprio Congresso é deixado de lado, quando não ludibriado e enganado pelapresidência imperial. Foi o que fez Lyndon Johnson, quando mentiu ao Congresso sobre o ataque a um navio estadunidense na Baía de Tonkin, provocando a longa e dolorosa guerra do Vietnã; foi o que fez Ronald Reagan, quando assessores imediatos e órgãos de inteligência desobedeceram leis do Congresso para financiar os Contra que lutavam contra o governo constitucional da Nicarágua; foi o que fez George W. Bush, quando ocultou a verdade ao Congresso sobre a existência de armas de destruição massiva em Bagdad, dando início à invasão genocida do Iraque.

Com a "doutrina de autodefesa preventiva" a presidência imperial põe em marcha duas estratégias: 1) o terrorismo de Estado no exterior; e 2) a aniquilação da democracia no país. A primeira, que é o terror de Estado, aparece na criação e no apoio aos regimes de segurança nacional na América do Sul durante a segunda metade do século XX, o que resultou em milhares de mortos, desaparecidos e 
exilados, sendo a Operação Condor uma de suas manifestações; na sustentação das ditaduras da Guatemala, da Nicarágua, da República Dominicana e do Haiti, todas "repúblicas bananeiras" que praticaram um verdadeiro genocídio contra suas populações pobres por mais de quatro décadas; na promoção e no financiamento de atos terroristas de toda espécie contra o governo socialista cubano, como a invasão armada à Ilha ou a guerra bacteriológica; no massacre dos comunistas na Indonésia, na morte dos nacionalistas no Iran, no assassinato dos independentistas no Timor Leste, na mortandade da guerra do Vietnã, do Iraque e agora do Afeganistão. Apenas nestes casos, o número de mortos se iguala aos crimes do regime nazista. As contrarrevoluções, organizadas e financiadas pelos Estados Unidos, têm sido muito mais violentas que as próprias revoluções, já que buscam ampliar os privilégios das elites locais e estrangeiras por meio de uma prática sistemática e duradoura do terror de Estado.

0 terror praticado por Estados, diz Chomsky, é funcional, já que melhora 0 clima de investimentos no curto prazo. Segundo ele, a ajuda de Washington aos governos inclinados ao terrorismo está em "relação direta com o terror e a melhoria do clima de investimentos e em relação inversa com os direitos humanos". Sendo os Estados Unidos um centro de poder, cujas opções políticas e estratégias calculadas produzem um sistema de clientes que praticam sistematicamente a tortura e 0 assassinato em escala assustadora, pode-se afirmar que Washington se tornou a capital mundial da tortura e do assassinato político. É o terror benigno, permitido aos Estados clientes que lutam contra o comunismo internacional, fazendo par ao terror construtivo, destinado aos Estados clientes que buscam manter e ampliar as áreas globais de investimentos estadunidenses (CHOMSKY; HERMAN, 1981, p.160).

A segunda estratégia, que é a aniquilação da democracia interna nos Estados Unidos, se dá por conta da eliminação dos princípios liberais, tais como o babeas corpus, o direito à livre expressão, a legalização da tortura como método válido para arrancar confissões de presumíveis terroristas e os julgamentos realizados por tribunais militares sem direito à constituição de um advogado. Acontece que, paralelamente ao crescimento da violência contrarrevolucionária no exterior, aumenta o desrespeito aos direitos humanos no próprio país. SaxeFernández chega a afirmar que, "se os nazistas se tornaram famosos [...] pelas cenas de seus soldados saqueando bibliotecas para logo em seguida fazer festas ao redor de grandes queimas de livros, agora a presidência imperial não fica atrás: adota a guerra preventiva; maltrata e brutaliza seus prisioneiros em Abu Grahib 
e Guantánamo, assim como ao longo do mar Índico em seus barcos-prisão da Marinha" (p. 240).

No livro de John Saxe-Fernández fica muito claro que a estratégia do terrorismo de Estado, praticada por Washington, tem como finalidade primordial a acumulação capitalista por meio dos investimentos de suas multinacionais. 0 trabalho é altamente explicativo e fundamental para entender a trama de poder que envolve, hoje, a presidência imperial dos Estados Unidos.

\section{REFERÊNCIAS}

CHOMSKY, Noam; HERMAN, Edward. Washington y el fascismo en el tercer mundo. México: Século XXI, 1981. 